\title{
Factors Affecting Covid-19 Disease Prevention Behavior in Bandar Lampung, Indonesia
}

\author{
Nova Nurwinda Sari, Annisa \\ Agata, Armen Patria \\ Nursing Study Program, Health \\ Faculty, University of Mitra \\ Indonesia \\ Email: \\ nova_sari@umitra.ac.id
}

Received : October 5, 2020

Accepted : November 27, 2020

Published : November 30, 2020

\begin{abstract}
Coronavirus Disease 19 or what we know as Covid-19 is a disease caused by coronavirus that can cause respiratory infections with mild to severe symptoms. Covid-19 disease can be prevented by the community if the community implements covid prevention measures such as using masks, diligently washing hands and keeping a distance. Preliminary preliminary survey note that the majority of respondents have not implemented the co-19 prevention behavior properly. The purpose of this study was to analyze factors that influence co-19 prevention behavior in Bandar Lampung. This research is a quantitative study with a descriptive analytic cross sectional design. The population and research sample using cluster sampling namely using 10 regions included in the Bandar Lampung area of 100 respondents. The research instrument used questionnaire sheets that had been tested for validity. Data analysis using chi square test. The results obtained data that there is a relationship between age (p-value 0.017), there is no gender relationship ( $\mathrm{p}$-value 0.878 ), there is a relationship between the level of education (p-value 0.000), there is a relationship of knowledge about covid-19 (p-value 0.029) with covid-19 disease prevention behavior in Bandar Lampung. The conclusion is that factors related to co-19 disease prevention behavior are age, education level, and knowledge of co-19. Suggestions should provide information about co-19 and the importance of co-19 prevention behavior continue to be given to the public.
\end{abstract}

Keywords: Predisposing factors, behavioral prevention, covid-19

Copyright (C) 2020 IIK STRADA Indonesia All right reserved.

This is an open-acces article distributed under the terms of the Creative Commons Attribution-ShareAlike 4.0 International License.

\section{INTRODUCTION}

At the beginning of 2020, there was a new type of virus that broke out and shocked the whole world, namely a new type of coronavirus called SARS-CoV-2 and the disease caused by the virus called Coronavirus disease 2019 (Covid-19) (WHO. 2020). The disease was first discovered in Wuhan, Hubei Province, China at the end of 2019, precisely in December (Bogoch, et a.. 2020). The origin of the transmission of this virus cannot yet be determined whether it occurs between humans and humans. However, currently the corona virus is still spreading rapidly in humans around the world.

According to WHO data in March 2020, a total of 90.308 individuals were infected with the Covid-19 virus. WHO data on August 17, 2020, a total of 21,516,760 individuals were confirmed with the Covid-19 virus spread throughout the world with a death rate of 766,663 . The highest cases 
of covid-19 are in America, with 11,561,554 cases 20. According to data from BNPB Indonesia on August 12, 2020, in Indonesia alone there were 130,178 covid-19 sufferers with a total of 85,798 patients recovered and 5,903 positive corona patients reported dead. This data is spread across 34 provinces in Indonesia (BNPB. 2020). WHO data as of August 17, 2020, in Indonesia as many as 139,549 individuals were confirmed positive for Covid-19 with a death rate of 6,150 (WHO. 2020).

According to data from BNPB Indonesia on August 12, 2020, in Indonesia there were 130.178 Covid-19 sufferers with a total of 85.798 patients recovered and 5.903 positive corona patients reported dead. This data is spread across 34 provinces in Indonesia. Meanwhile, in Lampung Province, 320 people were confirmed positive for Covid-19, with 230 patients being declared cured and 13 patients being declared dead (BNPB. 2020).

Corona virus 2019 (COVID-19) is one of the main pathogens that attacks the respiratory system in humans. Corona virus is a type of RNA virus with a particle size of 120-160 nm (Riedel. 2019). The coronavirus that causes Covid-19 is included in the genus beta coronavirus which is included in the same subgenus as the corona virus that caused the Severe Acute Respiratory Illness (SARS) outbreak in 2002 - 2004.

Currently the spread of the corona virus or SARS-CoV-2 from human to human is the main source of the spread of the disease so that this virus becomes more easily transmitted from one person to another. SARS-CoV-2 virus transmission originates from infected patients and spreads through droplets that come out when coughing or sneezing (Han and Yang. 2020). After transmission occurs, the virus will enter the upper respiratory tract and then replicate in the epithelial cells of the upper airway to carry out its life cycle and then spread to the lower airway. The incubation period of the virus until the disease appears is around 3 - 7 days (PDPI. 2020).

Comorbid hypertension and diabetes mellitus are risk factors for infection with the SARSCoV-2 virus. In addition, male gender and active smokers are also risk factors for this virus. Male gender is thought to be associated with higher active smoking than women (Cai. 2020). In addition, cancer patients and people with chronic liver disease are also more susceptible to SARS-CoV-2 infection. This is thought to be related to a decreased immune response in patients with cancer and chronic liver disease so that it is easier to catch the Covid-19 virus and can show worse symptoms (Bangash., et al. 2020). Research conducted by Guan et al. (2020) founded that out of 261 covid-19 patients who had comorbidities, 10 patients were cancerous and 23 patients had hepatitis B.

Yang, et al (2020) that COVID-19 patients with a history of respiratory system diseases will tend to have more severe clinical symptoms. Meanwhile, other risk factors for the SARS-CoV-2 virus determined by the Centers for Disease Control and Prevention (CDC) in 2019 are close contact with sufferers of Covid-19 and a history of traveling to areas affected by this virus. Whereas what is included as a low risk is being in an environment with a person with Covid-19 but not in close contact (within a 2 meter radius) (Centers for Disease Control and Prevention. 2020).

SARS-CoV-2 virus infection can cause several symptoms ranging from no symptoms (asymptomatic), mild, moderate and severe symptoms. The main symptoms that will appear in someone who is infected with this virus are fever (temperature $>38^{\circ} \mathrm{C}$ ), cough and experience difficulty breathing. Apart from these symptoms, sufferers can also feel shortness of breath, fatigue, myalgia and gastrointestinal symptoms such as diarrhea. Some patients experience shortness of breath within one week. However, in severe cases, there will be rapid and progressive deterioration such as septic shock, acute respiratory distress syndrome (ARDS), metabolic acidosis, bleeding or coagulation system dysfunction within a few days. However, in some cases, the symptoms that appear in patients include mild symptoms and are not even accompanied by fever (PDPI. 2020).

The incubation period of the SARS-CoV-2 virus ranges from 3 - 14 days with an average symptom found on day 5. During this periode, leukocytes and lymphocytes may still be normal or slightly decreased in patients who do not cause symptoms. In the next phase or early symptoms, the virus will spread through the bloodstream, especially to the lungs, gastrointestinal tract and heart. Symptoms in this phase are generally still mild. On the 4th to 7th days after the initial symptoms appeared, the patient was still feverish and began to experience shortness of breath and there were lesions in the lungs that got worse and there was a decrease in lymphocytes. This will lead to increased inflammation and will lead to hypercoagulation. If this condition is not resolved, then the inflammation will become uncontrolled in the next phase which will lead to ARDS, sepsis and other complications (Wang, et al. 2020). 
Yang, et al (2020), states that out of 52 critical patients, complications that occurred were not only RDS, but also other complications such as $29 \%$ of acute kidney disorders, $23 \%$ of cardiac injury, and liver dysfunction (29\%) and pneumothorax by $2 \%$. Other complications that have also been reported from infection with the SARS-CoV-2 virus are septic shock, disseminated intravascular coagulation (KID), rabdomyolysis, and pneumomediastinum (Huang, et al. 2020).

Until now, no antiviral or vaccine has been found to treat Covid-19 patients. Management that can be done is symptomatic therapy and oxygen. Mechanical ventilation can be performed in patients with respiratory failure 6 . For symptomatic and supportive management in patients with Covid-19 it can be through oxygen therapy, administration of antibiotics (especially in patients with sepsis), administration of corticosteroids for critical categories, administration of vitamin $\mathrm{C}$, etc. The management of the SARS-CoV-2 virus will certainly differ depending on the patient's condition because until now, antivirals and vaccines to treat the SARS-CoV-2 virus are currently in trials because this disease is a newly discovered disease (WHO. 2020).

With no antiviral or vaccine yet to be found to deal with the SARS-CoV-2 virus, knowledge about prevention of the SARS-CoV-2 virus also needs to be improved. The main key to preventing this disease is to break the chain of transmission through independent isolation, conduct early detection and perform basic protection (Ministry of Health, 2020).

The WHO recommendation for dealing with SARS-CoV-2 virus infection is to carry out basic protection which includes washing hands regularly using soap and running water / using a hand sanitizer, maintaining a minimum distance of 1 meter from other people, especially those who have symptoms of coughing or sneezing, and seeking treatment when have complaints in the suspect category (WHO, 2020).

In Indonesia, since the enactment of a disaster emergency status from February 29 - May 29, 2020, the Government has made various efforts to break the chain of transmission of the SARS-CoV2 infection (Koesmawardhani. 2020). The government continues to socialize basic protection measures such as washing hands using running water and soap, using masks when doing activities outside the home, doing social distancing and physical distancing. The public is encouraged to continue to apply this basic protection even though the Government has now issued a new normal policy, which means that people are allowed to carry out activities as usual but by implementing health protocols. However, many people do not respond to this wisely, and some people even ignore Government regulations because they take the virus lightly.

There are several factors that influence the health status of individuals and communities and play an important role in the success of a disease prevention program and prevention of transmission. Based on the problems from the background described and the importance of efforts to prevent disease transmission, research is needed to determine factors with Covid-19 prevention behavior in Bandar Lampung, Indonesia.

\section{MATERIALS AND METHODS}

The research design used was analytic with a cross sectional approach. The population in this study were all residents who live in Bandar Lampung with sample collection techniques using snowball sampling which was conducted from April 17 to April 24, 2020. Data collection was through a questionnaire using google form which was distributed using whatsapp media. There were 100 respondents who were scattered in 10 regions in Bandar Lampung.

In this study, univariate analysis was used to determine the frequency distribution of each variable and bivariate analysis was performed to determine the relationship between variables. Bivariate analysis using the chi square test with a significance level of $a=0,05$. Presentation of data using frequency distribution tables and cross tables.

\section{RESULT}

Based on table 1, it is known that based on gender, most of them are male, namely as many as 82 respondents $(82 \%)$, based on age, most of the categories of respondents are adults (aged $26-45$ years), namely 70 respondents (70\%), Most of the respondents with higher education level were 55 respondents (55\%), based on work as many as 100 respondents (100\%) worked, based on the level of respondents 'knowledge about Covid-19, most of the respondents' knowledge was good, namely 72 
respondents (72\%) and based on behavior Most of the respondents' behavior was good, namely 55 respondents $(55 \%)$.

Table 1. Frequency Distribution of Gender, Age, Education Level, Occupation, Knowledge of Covid-19 and Covid-19 Prevention Behavior

\begin{tabular}{lll}
\hline Variable & $\mathrm{N}(=100)$ & $\%$ \\
\hline Gender & & \\
Male & 82 & 82 \\
Female & 18 & 18 \\
Age & & \\
Adults, ages 26 - 45 years & 70 & 70 \\
The elderly, ages 46-65 years & 26 & 26 \\
Seniors, ages $>$ 65 years & 4 & 4 \\
Level of Education & & \\
Low & 4 & 4 \\
Medium & 41 & 41 \\
High & 55 & 55 \\
Knowledge About Covid-19 & & \\
Less & 8 & 8 \\
Enough & 20 & 20 \\
Well & 72 & 72 \\
Covid-19 Prevention Behaviour & & \\
Not Good & 9 & 9 \\
Pretty Good & 36 & 36 \\
Good & 55 & 55 \\
\hline
\end{tabular}

Source : Primary Data, 2020.

Table 2. Results of statistical tests between gender, age, level of education and knowledge about Covid-19 and Covid-19 prevention behavior

\begin{tabular}{lcc}
\hline Variable & N $(=\mathbf{1 0 0})$ & \% \\
\hline Gender & 82 & 82 \\
$\quad$ Male & 18 & 18 \\
$\quad$ Female & & \\
Age & 70 & 70 \\
$\quad$ Adults, ages 26-45 years & 26 & 26 \\
$\quad$ The elderly, ages 46-65 years & 4 & 4 \\
$\quad$ Seniors, ages > 65 years & 4 & \\
Level of Education & 41 & 4 \\
$\quad$ Low & 55 & 55 \\
$\quad$ Medium & & \\
$\quad$ High & 8 & 8 \\
Knowledge About Covid-19 & 20 & 20 \\
$\quad$ Less & 72 & 72 \\
$\quad$ Enough & & \\
$\quad$ Well & 9 & 9 \\
Covid-19 Prevention Behaviour & 36 & 36 \\
$\quad$ Not Good & 55 & 55 \\
$\quad$ Pretty Good & & \\
Good & & \\
\hline
\end{tabular}

Source : Primary Data, 2020.

Based on table 2, it is known that from a total of 82 respondents who were male - 46 respondents (56.1\%) had good Covid-19 prevention behavior, while of a total of 18 respondents who were female, 9 respondents (50\%) had good Covid-19 prevention behavior good Covid-19 prevention behavior. The test results obtained $\alpha$ p-value of 0.087 , which means that there is no relationship 
between gender and Covid-19 prevention behavior. The bivariate test results also showed that out of a total of 70 respondents in the adult age category (26 - 45 years), 39 respondents $(38,5 \%)$ had good Covid-19 prevention behavior, while from a total of 30 respondents with the elderly category (46 - 65 years) as many as 16 respondents (16,5\%) have good Covid-19 prevention behavior. The statistical test results obtained p-value 0,033 , which means there is a relationship between age and Covid-19 prevention behavior. The results of the bivariate test between the education level variable and the Covid-19 prevention behavior showed that from a total of 4 respondents with a low education level category, 3 respondents $(0,4 \%)$ had poor Covid-19 prevention behavior. Meanwhile, of the total 96 respondents with a secondary education level, 55 respondents $(52,8 \%)$ had good Covid-19 prevention behavior. The statistical test results also obtained a p-value of 0,000 , which means that there is a relationship between education level and Covid-19 prevention behavior. In addition, from a total of 8 respondents with a poor level of knowledge about Covid-19, 4 respondents $(4,4 \%)$ had good Covid-19 prevention behavior. Meanwhile, from a total of 92 respondents with a fairly good level of knowledge about Covid-19, 51 respondents $(50,6 \%)$ had good Covid-19 prevention behavior. The statistical test results also obtained a p-value of 0.010 , which means that there is a relationship between knowledge of Covid-19 and Covid-19 prevention behavior.

\section{DISCUSSION}

The results showed that most of the respondents were male, namely as many as 82 respondents $(82 \%)$. This is not in line with the results of research conducted by the LITBANGKES Agency of the Indonesian Ministry of Health which was conducted in 2020 that most respondents were female, namely 70,35\% (Badan Litbangkes Kementerian Kesehatan RI. 2020). The results of the study also showed that most of the respondents were in the adult age category (aged 26 - 45 years), namely 70 respondents $(70 \%)$. The results of this study are in line with research conducted by the Indonesian Ministry of Health's LITBANGKES in 2020, that most respondents aged 26-45 years were 50,51\% (Badan Litbangkes Kementerian Kesehatan RI. 2020). The results showed that most of the respondents' education level was high (Diploma / Bachelor's / equivalent) as many as 55 respondents $(55 \%)$. The results of this study are in line with research conducted by the LITBANGKES Agency of the Ministry of Health of the Republic of Indonesia in 2020, that the majority of respondents with higher education levels have graduated from D4 / SI, namely 42, 39\%. For the knowledge variable about Covid-19, it is known that the majority of respondents have a good level of knowledge about Covid-19, namely 72 respondents $(72 \%)$. Knowledge is the lowest cognitive aspect but the most important in shaping one's actions 14. Meanwhile, for the variable of covid-19 prevention behavior, the majority of respondents had good behavior, namely 55 respondents $(55 \%)$.

The results of the bivariate analysis showed that there was no relationship between sex and covid-19 prevention behavior. The results of this study are not in line with the results of research conducted by Fidah in 2020 that there is a sex relationship with physical distancing behavior with a pvalue of 0,001 . Fidah's research states that women are more likely to adopt good physical distancing behavior than men. This is because women generally adopt healthy behaviors such as meeting their needs for rest, relaxation and maintaining food compared to men (Fidah, et al. 2020). Another supporting research is Gita, et al research in 2016 which states that in general women are more responsible for their health than men so that women are more dominant in implementing healthy behaviors (Gita, et al. 2016).

The results of the bivariate analysis between age and Covid-19 prevention behavior obtained p-value 0,033 , which means there is a relationship between age and Covid-19 prevention behavior. If seen from the results, the majority of respondents are $>30$ years old. The age range of 36 - 45 years is a mature age where this age is considered to be capable or more skilled in healthy behavior compared to respondents aged <30 years. In addition, in the age range of $36-45$ years the individual will have good thinking and comprehension power so their level of knowledge will also be good (Wulandari, et al. 2020).

The results of the bivariate analysis between education level and Covid-19 prevention behavior obtained a p-value of 0,000 , which means that there is a relationship between education level and Covid-19 prevention behavior. The results of this study are supported by research conducted by Gita, et al, 2020 that there is a relationship between education level and PHBS behavior in households with a p-value of 0,000 . The formal education that a person has will affect their health behavior 
because education will affect their ability to digest information which will then be used as the basis for subsequent behavior (Gita. 2016).

The results of the bivariate analysis between knowledge and Covid-19 prevention behavior obtained a p-value of 0,010, which means there is a relationship between knowledge of Covid-19 and Covid-19 prevention behavior. The results of this study are not in line with research conducted by Fidah in 2020 which states that there is no relationship between knowledge and physical distancing behavior with a p-value of 0,875 (Fidah, et al. 2020). According to Notoatmodjo, knowledge is the result of knowing and occurs after a person senses a certain object. Without knowledge, a person has no basis in making decisions to determine action on the problem at hand (Notoatmodjo. 2011).

\section{CONCLUSION}

This study shows that there is no relationship between gender and COVID-19 prevention behavior in Bandar Lampung, Indonesia; there is a relationship between age and Covid-19 prevention behavior; there is a relationship between education level and covid-19 prevention behavior; there is a relationship between knowledge about Covid-19 and Covid-19 prevention behavior. Based on the results of this study, it can be suggested that the public should still be provided with health information about efforts to prevent Covid with various available health information media. In addition, to be able to behave healthily, the community does not only need health information but also needs examples and references from community leaders, religious leaders and support from health workers.

\section{ACKNOWLEDGMENTS}

The author is thankful to respondents for their valuable information and their awareness to participate in this research.

\section{CONFLICTS OF INTEREST}

The author declares that they have no conflict of interest

\section{REFERENCES}

Badan Litbangkes Kementerian Kesehatan RI (2020). Studi Kepatuhan Masyarakat Terhadap Himbauan Jaga Jarak Dan Perilaku Hidup Bersih Selama Pandemi Covid-19. Retrieved from https://www.humanitarianresponse.info/sites/www.humanitarianresponse.info/files/document s/files/paparan_hasil_survey_kepatuhan_150420.pdf

Bangash MN, Patel J, Parekh D. (2020). Covid-19 and the liver : little cause for concern. Lancet Gastroenterol Hepatol. Published online March 20. DOI : 10.1016/S2468-1253(20)30084-4

Badan Nasional Penanggulangan Bencana (2020). Update Sebaran Virus Corona Indonesia. Diunduh pada 12 agustus 2020 dari https://ternate.tribunnews.com/2020/08/12/update-sebaran-viruscorona-indonesia-rabu-1282020-dki-catat-529-kasus-baru-dan-819-sembuh?page $=4$

Bogoch, I. I., Watts, A., Thomas-Bachli, A., Huber, C., Kraemer, M. U. G., \& Khan, K. (2020). Pneumonia of unknown aetiology in Wuhan, China: Potential for international spread via commercial air travel. Journal of Travel Medicine, 27(2), 1-3. https://doi.org/10.1093/jtm/taaa008

Cai, H. (2020). Sex difference and smoking predisposition in patients with COVID-19. The Lancet Respiratory Medicine, 8(4), e20. https://doi.org/10.1016/S2213-2600(20)30117-X

Centers for Disease Control and Prevention (2020). Atlanta: Centers for Disease Control and Prevention

Fidah, S., Fika, M., Siti, ZI., Tri, AF., Hoirun N. (2020). Perilaku Physical Distancing mahasiswa UIN Syarif Hidayatullah Jakarta Pada Masa Pandemi Covid-19. Indonesian Journal Of Health Promotion and Behaviour, 2 (1) : 29 - 37

Gita, Gita Sekar P., Lista D. A., Habibi R., Arsinta I. I., Hanggara S. P., Galih R. P., Sinta F (2016). Faktor-Faktor Yang Mempengaruhi Tingkat Perilaku Hidup Bersih Dan Sehat Pada Tatanan Rumah Tangga Di Wilayah Kerja Puskesmas Poned X. Jurnal Ilmu Kesehatan dan kedokteran keluarga, Vol 14, No 1 tahun 2018.

Guan, W., Ni, Z., Hu, Y., Liang, W., Ou, C., He, J., Liu, L., Shan, H., Lei, C., Hui, D. S. C., Du, B., 
Li, L., Zeng, G., Yuen, K. Y., Chen, R., Tang, C., Wang, T., Chen, P., Xiang, J., ... Zhong, N. (2020). Clinical characteristics of coronavirus disease 2019 in China. New England Journal of Medicine, 382(18), 1708-1720. https://doi.org/10.1056/NEJMoa2002032

Han, Y., \& Yang, H. (2020). The transmission and diagnosis of 2019 novel coronavirus infection disease (COVID-19): A Chinese perspective. Journal of Medical Virology, 92(6), 639-644. https://doi.org/10.1002/jmv.25749

Huang C, Wang Y, Li X, Ren L, Zhao J, Hu Y, et al. (2020). Clinical features of patients infected with 2019 novel coronavirus in Wuhan, China. Lancet. 2020;395(10223):497-506

Ministry of Health (2020). Info Infeksi Emerging Kementerian Kesehatan RI. Retrieved from https://infeksiemerging.kemkes.go.id

Notoatmodjo. (2011) Kesehatan Masyarakat. Jakarta : Rineka Cipta

N.W. Koesmawardhani, (2020). Pemerintah Tetapkan Masa Darurat Bencana Corona hingga 29 Mei 2020. Detiknews. Diunduh pada tanggal 13 Agustus 2020 dari https://news.detik.com/berita/d-4942327/pemerintahtetapkan-masa-darurat-bencana-coronahingga-29-mei-2020

PDPI. (2020). Panduan Praktis Klinis: Penumonia 2019-nCoV. Jakarta: PDPI

Riedel S, Morse S, Mietzner T, Miller S. Jawetz, Melnick, \& Adelberg's Medical Microbiology. 28th ed. (2019). New York : McGraw-Hill Education/Medical; 2019: 617-22

Wang, C., Horby, P. W., Hayden, F. G., \& Gao, G. F. (2020). A novel coronavirus outbreak of global health concern. The Lancet, 395(10223), 470-473. https://doi.org/10.1016/S01406736(20)30185-9

World Health Organization. (2020). Coronavirus disease (COVID-19) advice for the public. Retrieved from https://www.who.int/emergencies/disease/novel-coronavirus-2019/advice-for-public

Wulandari, A, Rahman, F, et al. (2020). Hubungan Karakteristik Individu Dengan Pengetahuan Tentang Pencegahan Coronavirus Disease 2019 Pada Masyarakat Di Kalimantan Selatan. Jurnal Kesehatan Masyarakat Indonesia, Volume 15 No. 01, Mei 2020

Yang, J., Zheng, Y., Gou, X., Pu, K., Chen, Z., Guo, Q., Ji, R., Wang, H., Wang, Y., \& Zhou, Y. (2020). Prevalence of comorbidities and its effects in coronavirus disease 2019 patients: A systematic review and meta-analysis. International Journal of Infectious Diseases, 94, 91-95. https://doi.org/10.1016/j.ijid.2020.03.017 